\title{
Self-Reinforcing Mechanisms in Economics: with Two Case-Studies from Shipping Industry
}

\author{
Alexandros M. Goulielmos'1,2 \\ ${ }^{1}$ Maritime Division, Business College of Athens, Athens, Greece \\ ${ }^{2}$ Department of Maritime Studies, University of Piraeus, Piraeus, Greece \\ Email: agoulielmos@bca.edu.gr ag@unipi.gr am.goulielmos@hotmail.com
}

How to cite this paper: Goulielmos, A.M. (2018) Self-Reinforcing Mechanisms in Economics: with Two Case-Studies from Shipping Industry. Modern Economy, 9, 1313-1337.

https://doi.org/10.4236/me.2018.97085

Received: June 5, 2018

Accepted: July 28, 2018

Published: July 31, 2018

Copyright $\odot 2018$ by author and Scientific Research Publishing Inc. This work is licensed under the Creative Commons Attribution International License (CC BY 4.0).

http://creativecommons.org/licenses/by/4.0/

(c) (i) Open Access

\begin{abstract}
"Returns to scale", as a methodology, goes back to Adam Smith (1776). Economists after Marshall (1842-1924), with certain exceptions ${ }^{1}$, confined their interests exclusively to "Constant returns to scale". As a return they secured for their analysis a single equilibrium point with convenient convex curves. Early economists were sure that "resource-based" economic sectors like "Agriculture", "Bulk goods production" and "Mining" exhibited "diminishing returns to scale", a belief valid till this day. However, at least 9 important "knowledge-based" sectors exhibited increasing returns. More important is that increasing returns provides also no obstacle to growth of a firm, and of an industry...till it becomes a monopoly... We presented arguments against and in favor of this last theory drawn from Shipping and Marketing. Moreover, we examined the existence of increasing returns in relation to shipping industry and especially with 2 case-studies dealing with: 1) the exceptional economies of scale concerning "Vale S.A." and its giant ships "Valemax" of 400,000 dwt, double in size of existing ships (i.e. the Capes of about 200,000 dwt) and 2) the case of shipowners locked-in within the extremely high chartering markets during 2003-2008. The first was also examined in relation to the impact of "chance or small historical events". Traditional economists indeed did not have the mathematical tools to deal with "increasing returns" and "path dependence" till 1983, when "Arthur et al." discovered the "Urn schemes of the Polya kind". This method succeeded in combining probabilities or random facts with deterministic or chaos motions! This had a great impact on methodology, which, prior to that, dealt with either random or deterministic models in a water-proof separate manner. The aim of this paper was to mark out the importance of increasing returns,
\end{abstract}

${ }^{1}$ Young A 1928; Chamberlin 1933; Robinson J 1933; Palander 1935; Rosenstein-Rodin 1943; Myrdal 1957; Sraffa 1960; Maruyama 1963; Kaldor N 1970; Arrow and Hahn 1971; Arthur W. B. 1994.

${ }^{2}$ Schumpeter, 1954; Varian, 1990, Krugman \& Obstfeld, 2002. 
which has important implications in economic development policies, and comes from Complexity Theory and Chaos theory. With the first case study we showed, in addition, that market does not know best and small chance (historical) events, or mistakes, determine prevalence of a good or of a technical innovation. Moreover, we showed that in case of a lock-in, firms cannot do the best provided they have also the ability to foresee future. This analysis deals with a slice of Complexity theory.

\section{Keywords}

Increasing Returns to Scale, The Danger of Monopoly, Shipping Applications, Vale S.A. Case-Study, Lock-In Chartering Case-Study, Multiple Equilibria

\section{Introduction}

Conventional economic theory is structured exclusively on the assumption of "diminishing-returns-on-the-margin", meaning a local "negative feedback". Important alternatives, which were more difficult in their mathematics, like "positive feedback", and "increasing-returns-on-the-margin" (or "self-reinforcement") for long periods, were ignored. This provided an incomplete picture of the world around us.

Worth noting is that the sectors of an economy, which are resource-based, are for their most part subject to "diminishing returns". The sectors of the economy, however, which are knowledge-based ${ }^{3}$, are largely subject to "increasing returns". So nations with no resources can pursue their development counting on "knowledge", and also avoiding "Brain Drain", keeping the national brains... in house.

Worth noting is that most governments, and old fashioned economists, ignore the above distinction between industries and their resources. Greece e.g. depends heavily and perhaps exclusively, on "Tourism" and "Merchant Marine". These are two important exporting industries, no doubt, but subject, however, to abrupt cycles. Ignoring the knowledge-based industries and the strategy to create-through research-(or buying ${ }^{4}$-out)— "know-how" from the rest of the world, there are very limited ways for the country to grow.

Moreover, Agriculture in Greece was abandoned in favor of tourism as the second is lighter, of a shorter time ( $\sim 3$ summer months), and more profitable. Agriculture used to be also a recipient of "convenient" EU subsidies. The current crisis, 2009-2018, obliged certain young Greek people to return to Agriculture and related resource-based sectors. In addition Gold Mining in Greece is carried

\footnotetext{
${ }^{3}$ These are: computers, pharmaceuticals, missiles, aircrafts, cars, software, telecommunications equipment, fiber optics etc. Greeks in ancient times spent their time to philosophize. They had slaves to work in the non-mental endeavors. This knowledge-based advantage instead of continuing it, this was abandoned by modern Greeks losing their competitive advantage. Greeks are among the first worldwide minds in certain knowledge-based industries or research abroad.

${ }^{4}$ Certain nations tried to copy - to mention one less criminal version-the knowhow embodied in capital goods imported into the country from industrialized ones.
} 
out by foreign investors from Canada.

Moreover, the theory that an economy has to try to "replace imports by national production" has been abandoned too in Greece; $70 \%$ of all Greek needs-as it is argued-is satisfied by imports. Greece thus is a large "commercial center", mainly for European products, apart from imports of oil and gas.

Also Greece is a worldwide destination of about $20 \mathrm{~m}$ foreign tourists per year. It has the $1^{\text {st }}$ global shipping position under all flags, serving the $20 \%$ of world seaborne trade, with $310 \mathrm{~m}$ dwt in 2017 (for ships greater than $1000 \mathrm{gt}$ ); covering the $20 \%$ of EU fleet $(73.32 \mathrm{~m} \mathrm{dwt}$ ), as far as Greek flag is concerned, behind Malta (27\%) and before Cyprus (10\%) in 2017. Greeks remain a dry cargo transporter with $48.5 \%$ share in dwt in Jan. 2018 followed by tankers (35\%), and $22 \%$ in the world fleet ${ }^{6}$ of dry cargo ships (Jan. 2018) (29\% in tankers).

\section{Aim and Structure of Paper}

We plan to show indirectly that Economies, like that of $\mathrm{Greece}^{7}$, which are deprived of resources, can rest their hopes on knowledge-based industries for further development. This hope, however, is based on admitting that "increasing returns"-IRS exist. The aim of this paper is to apply a particular portion of the economic literature on "increasing returns" and "path dependence"-which emerged in 1994-to shipping industry. This portion will deal with: 1) economies of scale, 2) lock-in (within profitable spot markets), 3) multiple equilibria and 4) the effect of "chance effects" on technology and its expected adoption by market.

The paper is organized as follows. Next, there is a literature review followed by the methodology. Then, established theories of production and cost are presented. Next, the Marshallian belief that firms can become monopolies if IRS prevails is considered. Then, the "self-reinforcing mechanisms" are presented with application to 2 case-studies in shipping. Finally, we conclude.

\section{Literature Review}

Smith A [1] dealt, in 1776, with "increasing returns to scale"-IRS. He wrote: "the power of exchange gives occasion to the 'division of labour', the extent of which is limited by the extent of the market" (narrated; bolds added). Smith placed great emphasis on this principle implying that "an increase in productivity" is also limited by the "division of labour".

Cournot [2], argued, in 1838, that "Perfect Competition" is not compatible with "IRS"... He-as a result-developed models of oligopoly/duopoly.

Mill [3], in 1848, argued that Agriculture operates under conditions of "diminishing returns" and Industry operates under conditions of IRS. He (in chapter ${ }^{5}$ The import substitution theory was one of the main development strategies chosen by developing countries after $2^{\text {nd }}$ WW. However, Greece being in the EU single market, its development has to be carried-out only through competition, and thus national products can replace EU ones, mainly on terms of quality and price.

${ }^{6}$ Data from Greek shipowners Union's 2017-18 annual report.

${ }^{7}$ Greece has not been endowed with oil or iron ore, but lignite; it also endowed with Sun, Sand, Sea and Ancient Monuments. It developed... as a result the "Tourism" and "Merchant Marine" sectors. 
9) for the first time discussed the forces ${ }^{8}$ making-up IRS. He also predicted an increase in the scale of business firms in the course of economic progress-prediction often attributed to Marx [4]. Mill had in mind the case of a long run downward-sloping supply curve in case an industry operates under "IRS" (Figure 1).

Mill also realized, (book 3, chapter 18, section 6), in using Marshall's diagram on foreign trade, that when country A's or B's "offer curve" bends backward-due to an inelastic demand-multiple equilibria are possible and the terms of trade cannot be determined [4]. Also, Jevon's S. (1835-1882) treatment of the "isolated exchange" did not produce a determinate solution (how could it be?) with one equation with 2 unknowns. In the case of a "barter exchange" multiple equilibria and the possibility of unstable ones is possible. Competition does not preclude multiple equilibria [4].

Marshall [5] argued that the elasticity of supply of a commodity, conforming to law of "increasing return"... is theoretically $\infty$ for long periods; this implies that there are no limits to growth in the size of firms [6]. For Marshall in order to avoid monopoly: 1) firms should have a life cycle in their products, presented below; 2) "real" "external economies" should exist and 3) dependence on marketing has to exist too, presented also below. Marshall noticed the indeterminacy created when firms, with long-run decreasing cost curves, compete for a market share. Marshall expanded also on matters of the implication of IRS, plus economic growth, irreversible supply curves and externalities.

Schumpeter, in 1954, admitted that the case of multiple equilibria is not necessarily useless, but from the standpoint of any exact science, the existence of a uniquely determined equilibrium is, of course, of the utmost importance [7].

Further developments came along the above line, but not in full, from: Chamberlin E. and Robinson J. in 1933; by Young A in 1928, Kaldor N (1908-1986) in 1970, Graham F (1923), Sraffa ${ }^{9}$ (1898-1983) in 1960, Palander

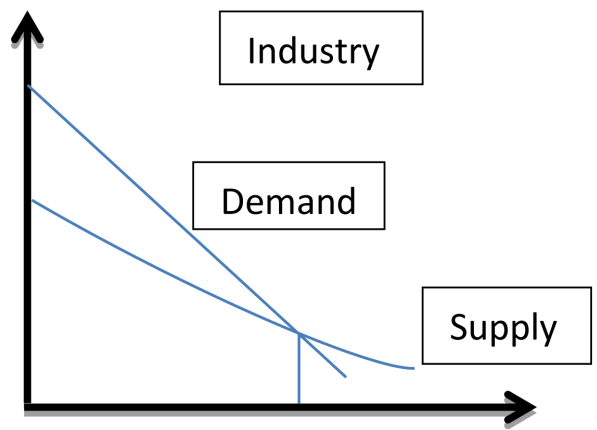

Figure 1. Demand and supply curves with a downward-sloping supply, showing IRS.

${ }^{8}$ Mill [3] has been influenced by Charles Babbage's book in 1833: "Economy of Machinery and Manufactures".

9In his paper "the law of returns under competitive conditions", which appeared in 1926 in Economic Journal, he raised the question of the nature of increasing returns and whether it was compatible with competition, a question raised also by Cournot 88 years before. 
T in 1935 and Maruyama M in 1963. By early 1970s economists were stuck by another idea [7] that all properly specified economic problems should show a unique equilibrium solution, based on sufficient convexity of the curves involved: implying diminishing returns...

"General-equilibrium" and "game" theorists knew, for many years, that multiple equilibria and indeterminate solutions exist in economics. This manifested by several authors i.e. by: Smith [1] in "specialization"; Marshall's hopes for “organic economics" [5]; Rosenstein-Rodin in "big push" (in 1943); Myrdal ${ }^{10}$ G K (1898-1987) in "cumulative causation" (in 1957); and Kaldor N (1908-1986) in "regional disparity" (in 1970). Walras [8] believed, in 1874-1877, that the existence of a general equilibrium solution requires only an equality of "the number of equations with the number of unknowns". This was not correct. Even 2 independent and consistent equations-and if nonlinear-produce multiple equilibria as the curves intersect not once, but several times (as in Figure 2 and Figure 4).

The main breakthrough, however, on the issue of IRS has been made from 1979 to 1994, especially with the seminal work of Arthur [7]-as editor-containing 10 papers (1982-1992)). Before that we had the work of Arrow and Hahn [9]. As argued by Arrow [7], both Ricardo D (1772-1823) and Mill J S, rejected the statement of Smith about the "extent of the market". Smith required "increasing returns" to explain "specialization" and "economic growth"-i.e. his two basic factors he needed to explain the causes of the "wealth of nations"... i.e. how certain nations are rich and others are not.

Moreover, Smith showed how "transportation" and "communications" could reduce costs, something which re-discovered by Marshall, 100 years later. Arrow

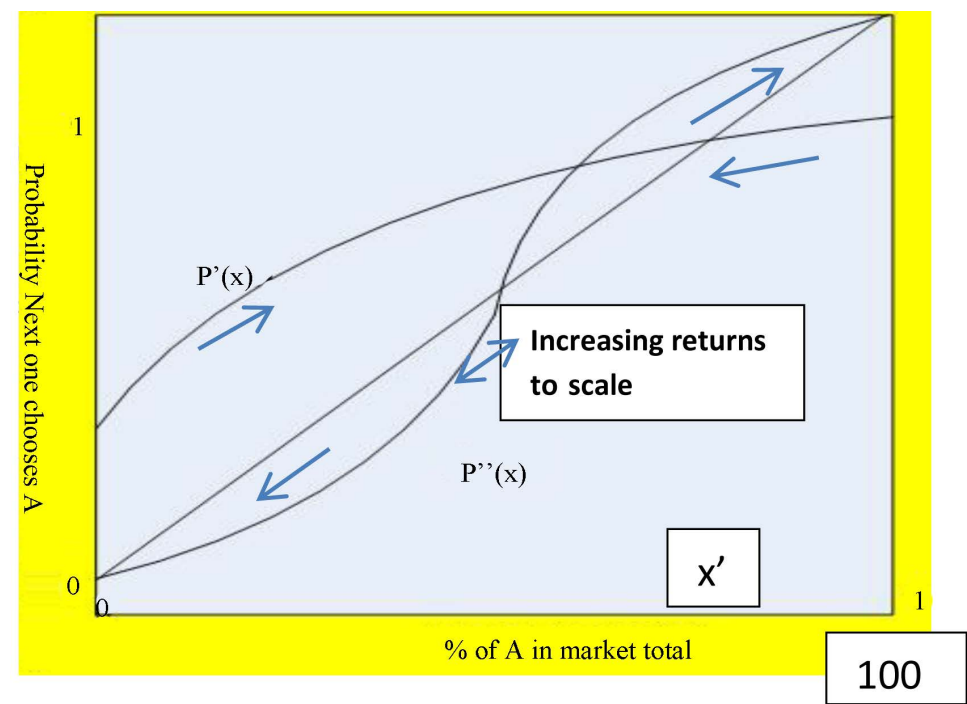

Figure 2. Two allocation functions, for $K=2$. Source: Inspired by Arthur [7], Arrows indicate the likely directions of motion.

\footnotetext{
${ }^{10}$ In his "Economic theory and underdevelopment regions", London, Duckworth, Myrdal argued that the self-stabilizing mechanism of the neoclassical approach is not functional in real economies. He advanced the theory of "cumulative causation" based on IRS. In fact this means "self-feedback causations" or "positive feedback".
} 
[7] argued that the need to reach: a "competitive system", a "cost-of-production theory of value" and a "rigorous treatment", obliged economists to introduce "constant returns to scale" - CRS...

The main literature about IRS appeared in 1971 (-1986) with the works of Arrow and Hahn [9], as mentioned, and 13 additional papers. Reader can read the papers of Katz and Shapiro [10] [11], Kehoe [12], and the work of Schelling [13].

Varian [14] argued that CRS is the likely outcome as firms replicate their past and this is the natural case...

As a conclusion we may say that in early 1990s, economic theory produced the "new economic geography" or "geographical economics". One economist who was very active during the last 30 years, on this new development, was Krugman $\mathrm{P}^{11}$. He with Obstfeld [15]-devoted a chapter (no 16) on economies of scale-were followed by Venables $T$ and Faini (in 1984). A main work is that of Fujita, Krugman and Venables [16].

Baldwin [17] has also contributed in the discussion. In addition, Saxenian [18] wrote specifically on Silicon Valley at California and on 128 highway of Boston. Krugman [19] argued that as silicon Valley makes clear, the economic analysis of location - the geography of the economy-is the subfield of economics to which the typical buzz words of complexity apply most obviously and dramatically.

In summary, we see that the early economic writers explored all possible situations in the production of firms, i.e. constant-CRS, decreasing-DRS and increasing-IRS, returns to scale, unlike modern writers, who restricted their analysis to CRS. In shipping, IRS is inherent in the construction of ships where by increasing the size of a vessel, there is no need to increase proportionally the materials used. Moreover, modern writers ignored the possibility of multiple equilibria, and the probable case where an "inferior" technology can be selected by the market, due to "chance effects" ("Qwerty" typewriter keyboards, in 1873; Paolo Uccello clock in 1443; VHS videocassettes; Microsoft Windows and MS-DOS on desktop PCs). Economists resorted exclusively to convex curves, pre-assuming that a unique and convenient equilibrium is (or has to be) the only possible outcome... meaning CRS.

\section{Methodology}

Suppose there is a unit of a product or service or technology for sale/adoption at an event time. How can its choice be distributed among $\mathrm{K}$ different market products etc.? This clearly is a probabilistic problem. The probabilities are functions of the proportions of units currently in the $K$ categories, where $\boldsymbol{x}$ is the "current market shares" vector. Moreover, there is the "allocation" function: $p=\left[p_{1}(x), p_{2}(x), \cdots, p_{K}(x)\right]\{1\}$, which maps the "unit simplex $S^{K}$ of the proportions into the unit simplex of probabilities" [7]. If a service etc. is selected by users by majority, due to chance reasons, then this prevails against compet-

\footnotetext{
${ }^{11}$ Geography and Trade, 1991, Cambridge, Mass.: MIT Press, where he dealt with IRS.
} 
itive services etc....

In more detail: let the process start at time one with an initial vector of allocations: $\boldsymbol{y}=\left(y_{1}, y_{2}, \cdots, y_{k}\right)\{2\}$, at an initial total of: $w=\sum y_{i}\{3\}$. The vector describing the number of units in categories 1 through $K$, at time $n$, where $w+$ $(n-1)$ units are allocated, is: $Y_{n+1}=Y_{n}+b\left(X_{n}\right)\{4\}$, where $Y_{1}=y$ and $b$ is the $j_{\text {th }}$ unit vector with probability $\mathrm{p}_{\mathrm{j}}\left(\mathrm{X}_{\mathrm{n}}\right)$. Dividing $\{4\}$ by total units $(w+n)$, the relevant shares are: $X_{n+1}=X_{n+1} / n+w\left[b\left(X_{n}\right)-X_{n}\right]\{5\}$, where $X_{1}=y / w$.

Now, we can add $1 / n+w \xi\left(X_{n}\right)$ to $\{5\}$, where $X_{1}=y / w$ and $\xi\left(X_{n}\right)=b\left(X_{n}\right)-$ $p\left(X_{n}\right)=$ the random factor. Equation $\{5\}$ describes the dynamics of the shares, which are driven by the "equivalent deterministic system" $\{6\}$ (given below) together with a perturbation effect! The (expected) motion of the shares is: $E\left(X_{n+1} \mid X_{n}\right)-X_{n}=1 / n+w\left(p X_{n}\right)-X_{n} \quad\{6\}$; this is the "equivalent deterministic system" corresponding to the stochastic process mentioned above. This means that if the probability $p_{j}\left(X_{n}\right)$ of an addition to category $j$ is $>$ than the current proportion $x_{j}(n)$ in category J, this category's share (expected to) increases. As shown (Figure 2), the process corresponding to $p^{\prime}$ converges to $x^{\prime}$ with certainty; the process corresponding to $p^{\prime \prime}$, converges to 0 or 1 , with certainty too.

The above methodology is simple, but as often happens, simple theories are more difficult to prove. The mathematics involved is due to Arthur et al. in 1983 [20]. The idea was to find out which product, service or technology etc., will be selected-looking at the way each unit selected is added to the already existing ones (or to zero ones at the start). They proved that the proportions of each product, etc. must settle down to a "fixed point" of the relevant "probability function". We will refrain from proving this here.

Increasing returns is shown (in Figure 2 \& Figure 4), where 2 equilibrium points are shown: one at $100 \%$ and one at $0 \%$. Constant Returns to scale are shown (Figure 3 ), with a single equilibrium point, characteristic of it as mentioned.

The multiple equilibrium points is a combination of IRS and DRS (Figure 4).

\section{Established Theories of Production and Cost}

All firms are interested to find-out what will happen if increased their size. We

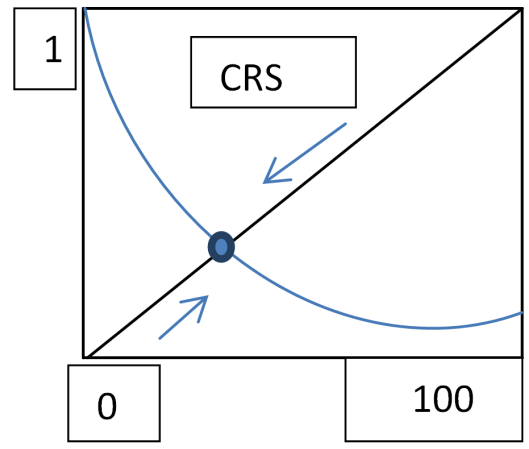

Figure 3. Constant returns to scale with a single equilibrium point. Source: inspired by Arthur [7], p. 7. 


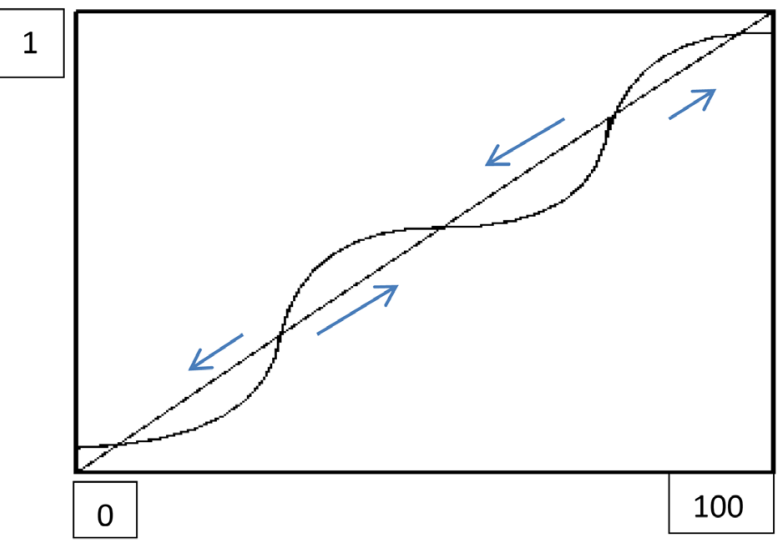

Figure 4. The combination of increasing and diminishing returns yield multiple equilibrium points. Source: Inspired by Arthur [7].

believe that a "competitive advantage" from a greater size of plant (=scale ${ }^{12}$; ship size; number of ships) can be obtained in two ways: 1) first technically, from the production process - in physical terms, and 2) and more important-from "outlays"-i.e. economically (in money terms). The first occurs, when a firm increases the quantities of all factors of production, it commands-i.e. all inputs ${ }^{13}$. Theory says that this is possible only in the long-run. The second occurs when input prices are allowed to change. If inputs can be used in various quantities, (with a potential substitution too), then cheaper inputs are better used in production in greater quantities than hitherto, so that to minimize firm's production cost. This is the objective of all firms and of shipping ones: "minimize cost".

Imagine now that production-engineers conceived the "theory of production" and economists conceived the "theory of cost"... The theory of production exists only.... at the stage of desires - and tells us which one-from $\infty$ combinations of quantities of factors of production (inputs) - a firm desires to use to obtain a certain output, by using a minimum amount of inputs (="technical efficiency")...To find-out what firms can realize-from all their desires-"isocost lines"

${ }^{12}$ All managers understand "economies of scale"-or economies due to size-theoretically or empirically. Onassis e.g. believed in them in the tanker businesses; he was justified by history, except when 1st oil crisis occurred. Onassis forced shipbuilders to "exceed their limits" in the size of his "super-tanker" "Ariston". Economies of scale, however, are limited by the extent of the market. In other words, the market (the importer) determines each time the maximum amount that can be transported at once-i.e. per voyage-from a well to a refinery, given distance, refinery capacity, port capacity, price of oil, etc. It is not irrelevant that today oil companies charter-by great majority-vessels that are either "Aframax" (1/2 m barrels at a time) or "VLCC" (2 m barrels at a time)... though there are also larger (ULCC) and smaller tanker ships.

${ }^{13}$ Economists replaced the term "factors of production" with "inputs". This allows for many inputs in shipping, like fuel, interest on money (for revolving capital), spare parts, chemicals, lubricants, diesel, stores, paints, water, provisions, etc., to be included in production, apart from capital and labor, which are the 2 classical factors of production. Shipping uses sea as the third factor of production, which is free, unlike land for which we pay for. Japanese added the "inventory cost" of raw materials etc. as a $4^{\text {th }}$ factor of production. We may call this factor of production "stand-by unproductive capital embodied in spare parts and raw materials and other necessities for a future production", which led to "just in time" and "door to door". 
are required. Moreover, determining isocost lines is a "dynamic" process in so far as it allows the use of changeable prices of inputs.

In matters of production, however, technology is crucial.

$\checkmark$ Choice of technology

Technology, and technology of ships, is "fixed" in the short-run. This means that production is "determined" 14 by current technology or in others words: technology appears in vintages [21], like the wines and ships [22]. Technology ${ }^{15}$ rarely anticipates future developments, as it should.

We saw entrepreneurs, however, to subordinate technology to their vision, and be successful (e.g. Onassis), helped by the right demand (a chance event). Studies on "maritime technical progress", however, are missing; i.e. cases where "more output is produced with the use of the same quantity of inputs" ${ }^{16}$. On the contrary, what has been frequently recorded in shipping is to "produce proportionally more output with an increased-but lesser-quantity of inputs" (=economies of scale). This is shown also in the case-study of "Valemax" ships (mentioned below).

Is technical progress something like "manna falling from Heaven"? Technology obliges managers to intervene-as far as they can-after delivery ${ }^{17}$ of their capital goods...at an after sales cost. Anyway, technology should also take into account not only economic, but also environmental, safety and human factors at the time of construction [23]. Moreover, there are times, when technologies compete one against the other (e.g. mobile phones; TV sets; fuel for cars, etc.).

\section{$\checkmark$ Stages in production}

The possible outcome in production can be: "constant, decreasing or increasing", when using an increased amount of inputs. Interesting is increasing returns. In popular saying this last means the first million $\$$ is difficult...Money gives birth to more money, as mentioned below.

\section{$\checkmark$ Returns to outlay}

If inputs have technical substitution, this is an additional degree of flexibility. In shipping, a vessel can produce a specific production-if loaded-over a specific distance, an economic speed, and with certain cargo handling means etc. Also, ship's production depends on time at sea and in ports (+weather condi-

\footnotetext{
${ }^{14}$ Historically we have met ship owners-ex marine engineers-to intervene in the construction of their newly-built vessels and make them more efficient or more suitable for crew or more ergonomic. Technology provides standardized technological products and it is important for shipbuilders to have a "research and development" department. The cooperation between shipowners, or their representatives, who know the demands of their charterers, and shipbuilders, may bring great benefits to shipowners. Shipbuilders, however, pass the improvements to their next customer and a possible competitive advantage this way does not last. It is important for a large shipping company to have also a research and development department.

${ }^{15}$ When the price of oil increased beyond any expectations in 1970s, marine engineers designed new fuel-saving engines...making less rounds per minute...

${ }^{16}$ This obviously involves time. Increased production in shipping with same inputs can be done if production is done faster.

${ }^{17}$ We saw also shipping firms to replace ship's main engine or replace ship's cargo-handling equipment, intervene in propeller's shape and making ship larger to mention a few interventions; also, ship's bottom cleaning etc.
} 
tions), nature of cargo and condition of ports (congestion, waiting etc.). Moreover, time is so important in shipping so that to say that a vessel has to have one only objective, apart from minimizing cost: "zero off-hire time" or "ballast time". And this is so as a vessel "produces" only if "in hire/in charter" (loaded) and the number of her voyages is maximized.

$\checkmark$ Runs in economics

Economists present the phenomenon of returns to scale as taking place in consecutive stages over calendar time in one and the same firm. This is a fictitious method to slice production time in 4 - 5 periods: market, short-run, (medium-run), long-run and very long-run [5] or even secular-run-over 60 years on average [24]. Moreover, as shown in the methodology, a firm with all stages of returns to scale will encounter from one to many equilibrium points in its life time...something mentioned here for the first time.

In the short-run, some inputs cannot change, as they need time, like building a vessel. To find crew for a vessel, or fuel, is a fast procedure. So, economists assume that if an input cannot increase-due to limited time ${ }^{18}$-output cannot increase as much as if all factors of production increased. This is the situation of "decreasing returns to scale". In Agriculture e.g., land and machinery may remain fixed, while workers may increase (=short run).

$\checkmark$ Ship's isoquants

Is there one combination of the quantities of inputs so that to get the maximum outcome? Yes! Out of a number of $\infty$ combinations of inputs we are able to choose the best one. A vessel say of 50,000 dwt "needs" 18 persons to run; this cannot change after delivery. Ship's isoquants are thus right angles (Figure 5).

As shown, 3 "isoquants" ("equal product curves") in shipping, have a different but fixed amount of factors of production-labor (number of crew) and capital (vessel's value). Law $^{19}$ and technology, as well management, fix the number of crew for a specific vessel. The capital/labor ratio is thus fixed for a specific vessel

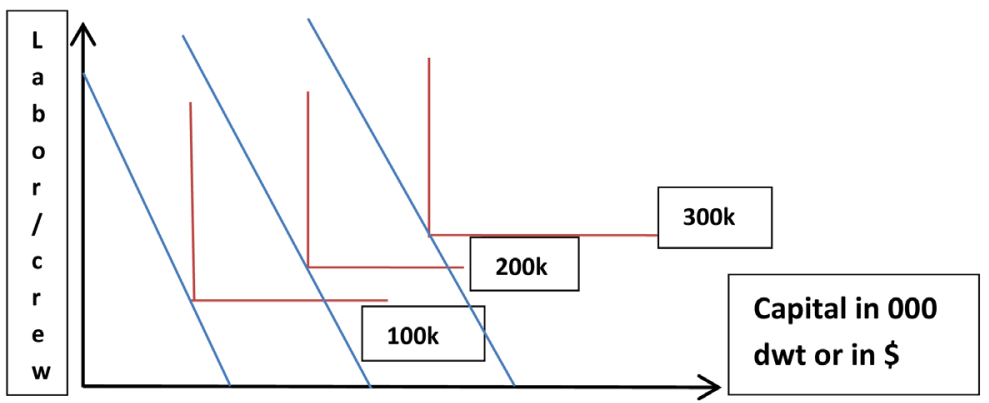

Figure 5. Shipping isoquants \& isocosts.

${ }^{18}$ Time is one reason. We may add also and other reasons that restrict the supply of an input. Shipowners frequently complain that they are unable to find the "proper" number of officers for their ships ("proper" meaning the quality of inputs coming from education, training, tradition, experience, seamanship etc.).

${ }^{19} \mathrm{Crew}$ complements are determined by Governments by law; shipowners are often pressing to have fewer number of crew, if automation is applied. Clever shipowners, however, care for their ships to have the proper number of crew for safety and for the amount of work involved, especially in tankers. 
and it could not change in the short run. Also an isoquant on the right side produces more output than the ones on its left side.

A larger and newer vessel due to automation etc. uses more labor, but not proportionally more in line with her increase in size. The size in Figure 5 increased 2 and 3 times respectively. Moreover, there are times, when technologies compete one against the other (e.g. mobile phones; TV sets; fuel for cars etc.).

$\checkmark$ Definition of IRS

Let a production function be one with 2 factors of production: $A=f(a, b)$ $\{7\}$, which if multiplied by $x$, gives $A=f(x a, x b)=x^{n} f(a, b)=x^{n} A$ \{8\}. If $n>$ 1 , then IRS exists.

\section{$\checkmark$ The efficient shipping manager}

$\mathrm{He} / \mathrm{she}$ buys or builds the more efficient-sized vessel for the trade he has ${ }^{20}$ in mind. A more efficient ship operates with fewer inputs than other ships of the same size, economic speed, handling equipment, cubic capacity, type, distance, time in sea and in ports, etc. The inputs are: the number of crew, quantity of fuel and diesel, lubricants, chemicals, water, stores, provisions, paints, maintenance cost, spare parts etc.

As shown, (Figure 6), two vessels have 2 different short run marginal costs curves, where the $2^{\text {nd }}$ shows IRS and a higher production per voyage in ton miles by a $\mathrm{qr}$ amount. In the short run, voyage's distance, ship's economic speed, vessel's size, time spent in sea and in ports, bunkers and diesel quantities, spare parts, etc. matter, while the freight rate per ton mile is given, determined by supply and demand. Input prices are considered constant and thus oil and diesel cost, port costs, crew wages etc. have to be excluded under this assumption.

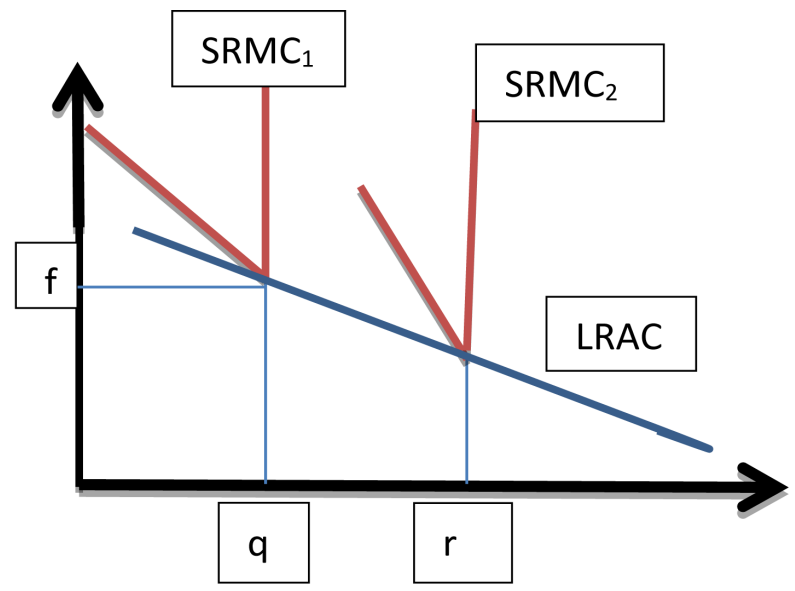

Figure 6. A shipping firm operates one vessel in the short-run producing $\mathrm{q}$ ton miles per voyage at freight rate $\mathrm{f}$. The firm can buy or build another vessel, 2, with lower SRMC and produce $\mathrm{qr}$ at a lower cost. Curve LRAC connects the lowest points of the 2 SRMC, as an envelope.

${ }^{20}$ In shipping when one buys a used vessel this is built with a trade in mind of her first owner. Thus shipowners have to fit a used vessel to the trade they intend to serve. Used vessels moreover have an age, and age has a history that has to be known to buyer. The most important past is ship's accidents and ship's maintenance. History here again matters. 
In the long run ${ }^{21}$, ship's size can change (as well age, if replaced), and vessel's speed, the speed of her cargo handling, as well crew number ${ }^{22}$. Usually "new plants-new ships" are either larger and younger, or newly-built. We assume that in the short run a shipping company may "forgive" a vessel to bring-in losses, but in the long run it will try to sell her, or lay-her-up, or scrap her.

\section{The Way Firms/Industries Become Monopolies}

Marshall [5] argued that "when the production of a commodity conforms to the law "of increasing return"... giving a very great advantage to large producers, it is apt to fall almost entirely into the hands of a few large firms". This statement means however oligopoly and not monopoly...

$\checkmark$ Almost all shipping firms in Greek-owned shipping have grown by leaps and bounds overtime, as shown elsewhere [6]; but the trend of set off of certain owners, split companies apart. This was not conceived by classical economists as deterrence to monopoly.

We showed [6] that a large shipping company created by father split in two by his two children after his death. The same happens when 2 or 3 brothers split off, quite common in Greek-owned shipping. Of course the opposite trend is also showed when companies merge by marriage among their owners-something also not conceived by classics-but this is common till this day in Greek-owned shipping [6]. The first tendency in the set off cases is an urge of taking business decisions independently; children always have a different opinion of how to do things vis-à-vis their fathers. The second is a tendency to keep wealth within the family.

Surely, the "extent of the market" plays important role, and in shipping, total demand is so vast, that an individual firm cannot be close to satisfy it entirely... In 2005, seaborne trade (=demand) was 6.78 billion tons that had to be carried over $\sim 4384$ sea miles on average [25] by $\sim 60,000$ or so ships. Moreover, the unit load of demand varies among trades meaning that different sized ships are required, and one firm has not all sizes of ships, but it specializes in them by size. Practically one large firm is difficult to become the only one in the various shipping trades.

$\checkmark$ Product's life cycle

If a product or service is subject to a life-cycle, then, eventually, it will reach a decline stage, and perhaps finally die, and drop out; thus product's monopoly cannot be realized for long. Buyers' preferences are not static and vary. As shown in Figure 7-where only changes in variables are shown-when a product/service is introduced in the market for the first time, both its sales and profits place its evolution in quadrant $1-\mathrm{Q}_{1}$.

This is so, for an increase in profitability (may) occur, while profits per unit

${ }^{21}$ Viner in 1931 showed that the long-run average cost curve of a firm is the envelope of all its short-run average costs curves.

${ }^{22}$ Theory assumes that the prices of inputs are constant. 


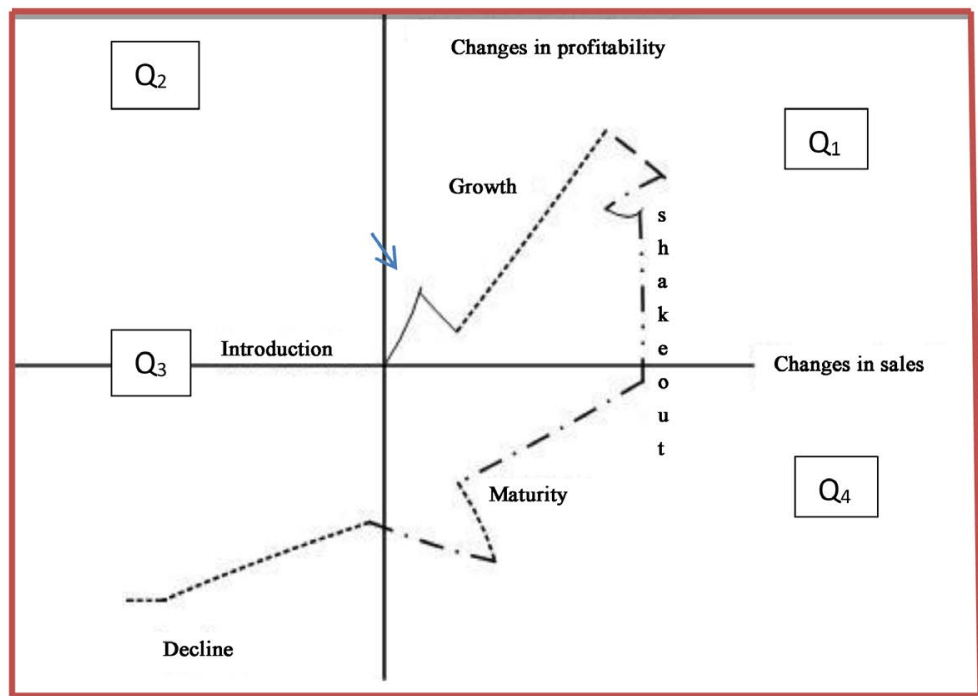

Figure 7. A hypothetical life cycle of a firm's product/service. Source: inspired from Priesmeyer [26].

may fall, as normally there have been high fixed costs at previous stages ${ }^{23}$ till a product is launched. When the product wins its acceptance among consumers, then both sales and profits $\left(\right.$ may $\left.^{24}\right)$ increase and push the trajectory further into $\mathrm{Q}_{1}$-this is the growth stage, where both sales and profits increase fast. A balanced growth - if any-would be moving along the $45^{\circ}$ degrees line (not shown).

In Figure 7, first annual figures are used to avoid seasonal influences. Secondly, changes in sales (horizontal) and changes in profitability (vertical) are adopted, using all four quadrants of the classical "Cartesian" diagram due to Descartes. Worth noting is that a product satisfies a need ${ }^{25}$ [27], and the need is the one that may show a life cycle, not product.

A need may: 1) pre-exist, 2) be forthcoming or 3) be created. A forthcoming need is seen only by entrepreneurs. A need can also be created by advertising, counting on certain human weaknesses. Also, we may count on ecology or, in general, on environment... Some have suggested for products in super-markets to bear a label saying that: "this product has been transported by an eco-vessel..."

When we come to existing needs, these may be satisfied by products produced by certain firms-competitors; then an "elimination" strategy of an antagonistic product is applied. We see that marketing is used not only for increasing one's sales, as thought by Marshall, but also for eliminating rival products from the ${ }^{23}$ Stages: conceive product's idea, design it, do market research, construct a pilot product, experiment, promote, establish delivery channels etc.

${ }^{24}$ We saw products that when first launched had high quality. We saw also products when first launched to have a low price. These products may create, however, the need to buy other supplementary products like spare parts, or even to have them later for service; thus whatever part of revenue is forgone by low pricing is re-obtained in the longer term with various strategies. In addition, we saw products followed by "after sales questionnaires" that used for further product improvement (e.g. Japanese cars).

${ }^{25}$ As Kotler (1994; [27]) said "marketing thinking should not begin with a product, but rather with a need". Moreover, the demand-technology-life-cycle is more important than product-cycle. 
market... Marshall failed also to evaluate what "homogeneity" ${ }^{26}$ of a product really means. It (homogeneity) first shows a tendency towards a monopoly, but secondly, a tendency towards a more intense competition...based on differentiation.

Certain authors suggest that product's design should be constantly changing, and thus the maturity stage of a product/service becomes something that can be prolonged ${ }^{27}$, or pushed back.

Theory talks about four classes of products: 1) the "well-managed winners", and 2) similarly the "well-managed losers" and 3) the "poorly managed winners" and 4) similarly the "poorly-managed losers". The first is when product/service market's share increases, belonging also to a growing industry. This is Marshall's case.

A "W-MW"-product belongs to a growing industry gaining an increasing market share; it appears in quadrant 1 in Figure 8. For this one may suggest to maintain, or even reinforce, its current (and successful) strategy. A "P-ML"-product suffers a decline in both market share and industry's growth, though it may help company's cash flow. One may suggest selling the product/service when its share is still high. A "W-ML"-product appears in quadrant 2 , where industry's growth is decreasing, but market's share is increasing. This may survive and avoid a shakeout; but it needs a market niche and an effort to increase its market's share. A "P-MW"-product appears in quadrant 4 , where its

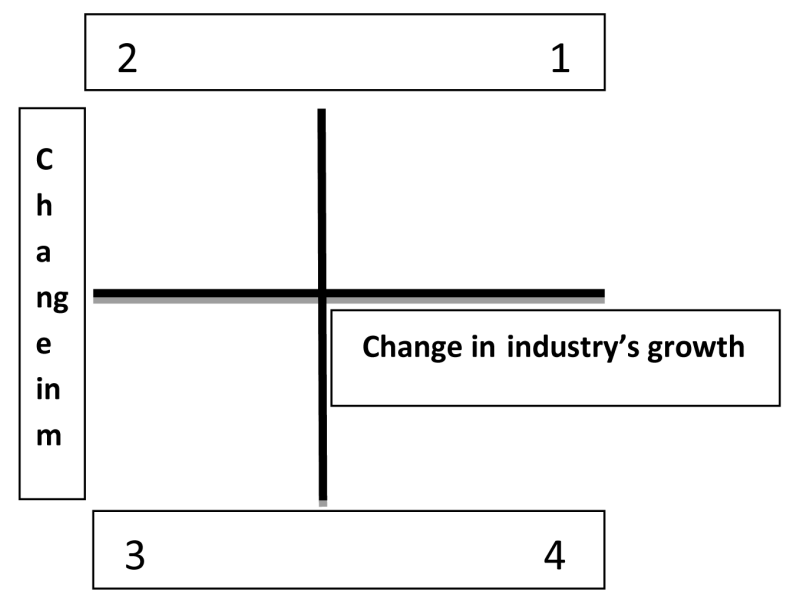

Figure 8. Changes in industry's growth and changes in market share in 4 quadrants $1-4$.

${ }^{26}$ For Marshall's case to be valid antagonistic products must be homogeneous, as then they are equivalent. But this property is psychological. Two products are homogeneous if perceived-as such by the consumer, regardless of the fact that these can be made exactly by the same quantities and qualities etc. of raw materials... We know that there is a number of Ps-e.g. promotion, price, place, package, people etc. that can differentiate a product from another... though equivalent in all other respects. Firms invented "product differentiation"—-sometimes imaginary-not only to antagonize a monopoly product, but also to increase prices in such a level extracting a profit greater than normal. Homogeneity... means perfect competition, and normal profits. Firms study first economics and then try to exploit it. Price is determined at the level of demand curve at the point when MC equal $\mathrm{MR}$, but Price can be $>\mathrm{MC}$ and $>\mathrm{MR}$ and $>\mathrm{AC}_{\min }$.

${ }^{27}$ Example: Arm \& Hammer Baking Soda. 
market share is decreasing, while industry's growth is increasing. The product needs a new assessment and design, further marketing, and a management effort to invest and differentiate product to reposition it in an expanding market.

$\checkmark$ Monopoly and IRS in rigorous terms

For monopoly one needs "stable fixed points at the vertices of the unit simplex". Let there be $K$ products etc. [7] and $n_{j}$ previous buyers, who bought product $j$. The next payoff for the buyer of $j$, is: $\Pi_{j}\left(n_{j}\right)=a_{j}+g\left(n_{j}\right)\{9\}$, where $a_{j}$ represents buyer's "natural preference" for $j$ from 1 to $k$, the function $g$ (monotonically increasing) represents the improvement that comes with previous buyers; " $a$ " is a vector of $k$ alternatives, which can be shown as a distribution of points - with a bounded support $\mathrm{Z}$-on positive quadrant (Figure 9).

Let a buyer be drawn at random from the probability distribution each time a choice is made. As shown (Figure 9), the "probability distribution" shifts either to the right of the $45^{\circ}$ line, or upward, as returns to A or to B increase, with each buying A or B. Monopoly then occurs when a positive probability of the distribution of payoffs is driven over the $45^{\circ}$ line, as the number of buyers becomes larger. To have a monopoly with certainty, then the improvement function $g$ has to increase without upper bounds, as $n_{j}$ increases, i.e. as in cases $\mathrm{Za}$ and $\mathrm{Zb}$ (Figure 9).

\section{The Self-Reinforcing Mechanisms}

We assume that economic outcomes are not predictable, problems have more than one solution and "chance events" may determine future [28]. Random events are magnified by inherent positive feedbacks, or reinforcing mechanisms, and may select an outcome-probabilistically-in IRS, using also nonlinear stochastic processes.

The self-reinforcing mechanisms are derived from 4 generic sources (Table 1).

Case 1.1 above is applicable to shipping, because shipping fixed costs are high and give the advantage of falling unit costs to increased output (=economies of scale). This is manifested by the case study of "Vale S.A.". Pursuing "economies

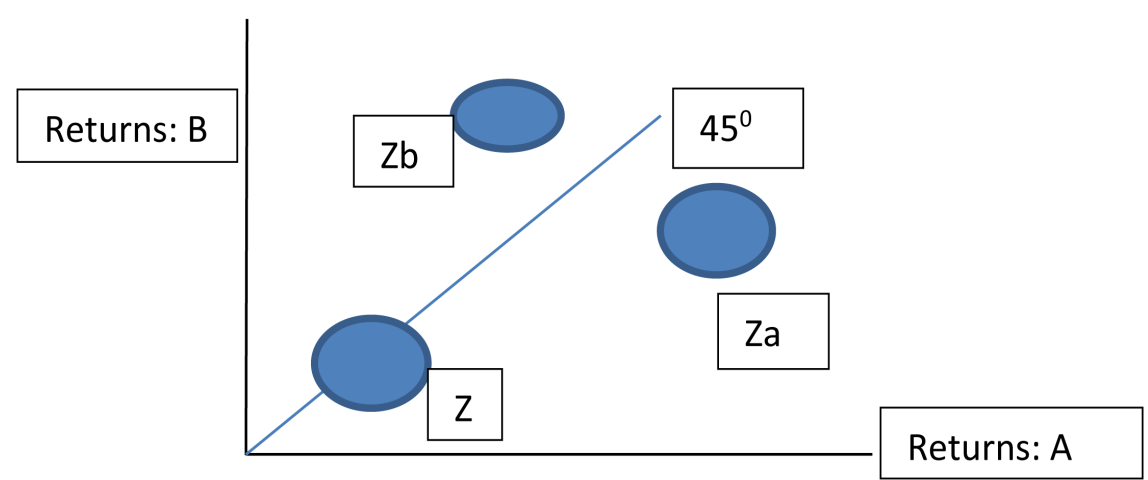

Figure 9. Distribution of payoffs to buy or to adopt A and B. Source: Modified from that of Arthur [7]. 
Table 1. The 4 generic sources of self-reinforcing mechanisms-IRS.

\begin{tabular}{cc}
\hline Large set-up, or fixed, costs (1.1) & Learning effects (1.2) \\
Coordination effects (1.3) & Self-reinforcing expectations (1.4) \\
\hline
\end{tabular}

Source: Author [7].

of scale 28 " and "economies of age ${ }^{29 "}$ are two basic strategies of Greek shipowners [6].

Case 1.2 is when we can improve service, or lower costs, as more ships of the company are chartered, (i.e. when prevalence increases). Lowering costs is a permanent strategy of Greek shipping companies, as mentioned. This case also implies higher liquidity, and the possibility to renew company's fleet through an improved cash-flow. Improvements in organizing the company and hiring new personnel of higher talents can also be done in this case. Clever shipping managers exploit this opportunity to build up "crisis reserves" to face an unexpected shipping depression. Company's built-up experience, related to company's age, we have found it important in shipping and of course there are learning effects in shipping companies.

Case 1.3 is when firms gain advantages by "going-along" with other firms doing similar actions, most probably in "maritime safety" (ISM Code) and "maritime security" (ISPS Code) matters, as well the adoption of latest IT technologies. Case 1.4 is when increased prevalence-increased number of company's ships being chartered-in the market, enhances the belief of further prevalence. This means that in shipping such a situation means either extension of an existing time charter or payment of a slightly higher hire. Shipowners compete also among them as to who is more adaptive to big oil charterers' demands, mainly to matters of maritime safety.

There are also 4 properties (Table 2).

Table 2 tells us-implicitly-that among 2 firms 2 quite different market shares are possible; but even this outcome is indeterminate, not-unique, and unpredictable. These 4 properties are shown in Table 3 more analytically.

$\checkmark$ Vale S.A. shipping case-study

Thirty six ${ }^{30}$ giant vessels, since 2011-and till May 2018-were built, owned (or chartered-in) by Brazilian mining company "Vale S.A.", planned to carry-in a substantial cheaper way-iron ore from Brazil to China... The size of these ships was more than double the usual hitherto size of 180,000 dwt of Capes, for the first time ${ }^{31}$ in the history of bulk carriers (Figure 10).

These ships have a length from 360 to $362 \mathrm{~m}$, with draft $22-23 \mathrm{~m}$, and 15 knots speed; and a size from 380,000 to $400,000 \mathrm{dwt}$ !

\footnotetext{
${ }^{28}$ This means to sell-in best timing-smaller ships and buy larger ones.

${ }^{29}$ This means to sell-in best timing-older vessels and buy younger ones.

${ }^{30}$ The ships were built as follows: in 2011: 6 ships; in 2012: 15; in 2013: 9; in 2014: 3; in 2015: 1; in 2016: 1 and in 2018: 1 (total 36); and 32 under construction for delivery in 2018-2020.

${ }^{31}$ Two exceptions are recorded for equal large or larger vessels in world shipping, like vessel "Berge Stahl", built in 1986, of 364,767 tons and before that the "Seawise Giant", in 1979, of 564,650 tons.
} 


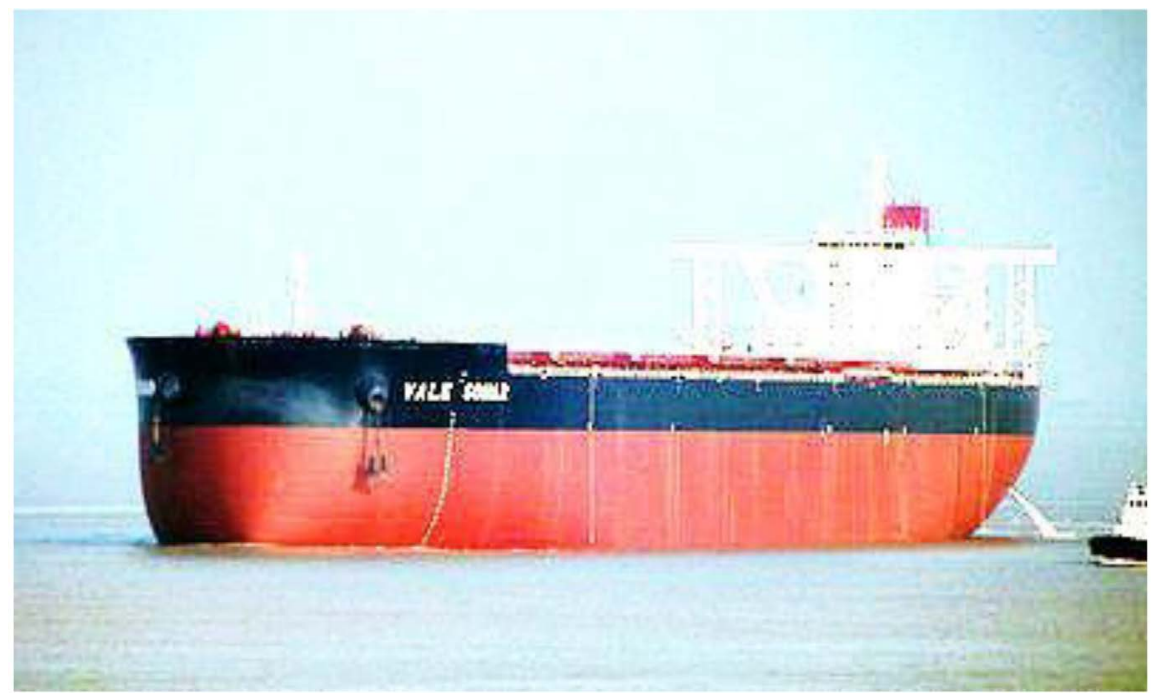

Figure 10. A Vale ship called "Valemax" or VLOC (very large ore carrier). Source: Goulielmos [24].

Table 2. Conditions existing in all markets showing if one service or the other will prevail.

\begin{tabular}{cc}
\hline Multiple equilibria (2.1) & Possible inefficiency (2.2) \\
Lock-in (2.3) & Path dependence (2.4)
\end{tabular}

Source: as in Table 1, p. 112-113.

Table 3. Conditions under which one service/product/technology must eventually take out all of the market.

Multiple equilibria: when 2 quite different asymptotic market shares solutions are possible; but the outcome is indeterminate, not-unique, and unpredictable

Lock-in: When a "solution" is reached, it is difficult to exit from it (in most chartering markets this has happened in 2003-2008)
Possible inefficiency: in case of one service, which may be "better"-in terms of a certain economic welfare criterion-but "bad luck" in gaining early users/adherents can lead to-a below maximum-benefit ("Vale S.A." case study)

Path dependence: when the early history of a market share, due to small events, and chance circumstances, can determine which solution will prevail ("Vale S.A." case-study)

Source: Arthur [7].

- Accusations against Vale S.A. for building the "Valemax"

Vale S.A. accused that the fleet of the first $12^{32}+7$ "Valemax" purposed to control the wildly fluctuating freight market for large bulk carriers. Indeed, these rates fell from $\$ 233,988$ per day (June 2008) to $\$ 2400$ (Dec. 2008), due to the meltdown in end 2008! Moreover, "China ship-owners' association" accused "Vale S.A." for seeking to control freight market as... it did with "iron ore prices". In addition, it has been accused for not building the ships in Brazilian shipyards ${ }^{33}$, something which we find quite right.

${ }^{32}$ The 1st delivered on 25/11/2011, the "Vale China", and the last in 23/01/2015, "the Ore Ningdo".

33"Vale S.A." ordered 19 ships; in S Korea 2 in 2009 and in China 3 in 2008 (03/08), delivered in 2011-2016. 
The $1^{\text {st }}$ ship cost $\$ 1.6 \mathrm{~b}$ in August 2008 , but by July 2009 , this fell to $\$ 423 \mathrm{~m}$, then up to $\$ 460 \mathrm{~m}$ (Det Norske Veritas journal, 9, Sept. 2008; Shipbuilding Tribune, 11/07/2011) and finally to $\$ 2.5 \mathrm{~b}$ for 30 units, due to shipping depression in

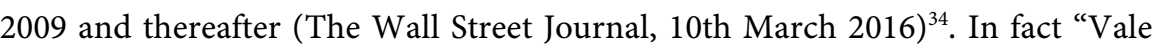
S.A." strong motive was to compete the Australian iron ore, which is much closer to Chinese markets vis-a-vis Brazilian one. "Vale S.A." right strike was to obtain a strong cost advantage by cutting down company's transport cost from $20 \%$ to $25 \%$ (Reuters, $17 / 06 / 2011$ ), thus being in a position to exterminate ${ }^{35}$ all company's competitors.

$\checkmark$ Valemax Shipowners' mistake

Shipowners usually commit a mistake when ordering ships: they do not forecast the condition of the specific freight market at the time of the delivery of ships. This is an event, which will emerge a number of months or years after ordering... The first 12 "Valemax" ships delivered from 25/11/2011 till 23/01/2015. For us to see the market conditions at delivery we may look at the Cape marketa closer size to Valemax (Figure 11).

As shown, the index started at 1438 units (blue), close to Jan. 2012, and ended at 199 in March 2016...They were some peaks in 2013 and in 2014, which could be used for a shipowner to fix a time-charter, which is required for new-buildings in a volatile market. "Vale S.A." could of course time charter each vessel before building her...

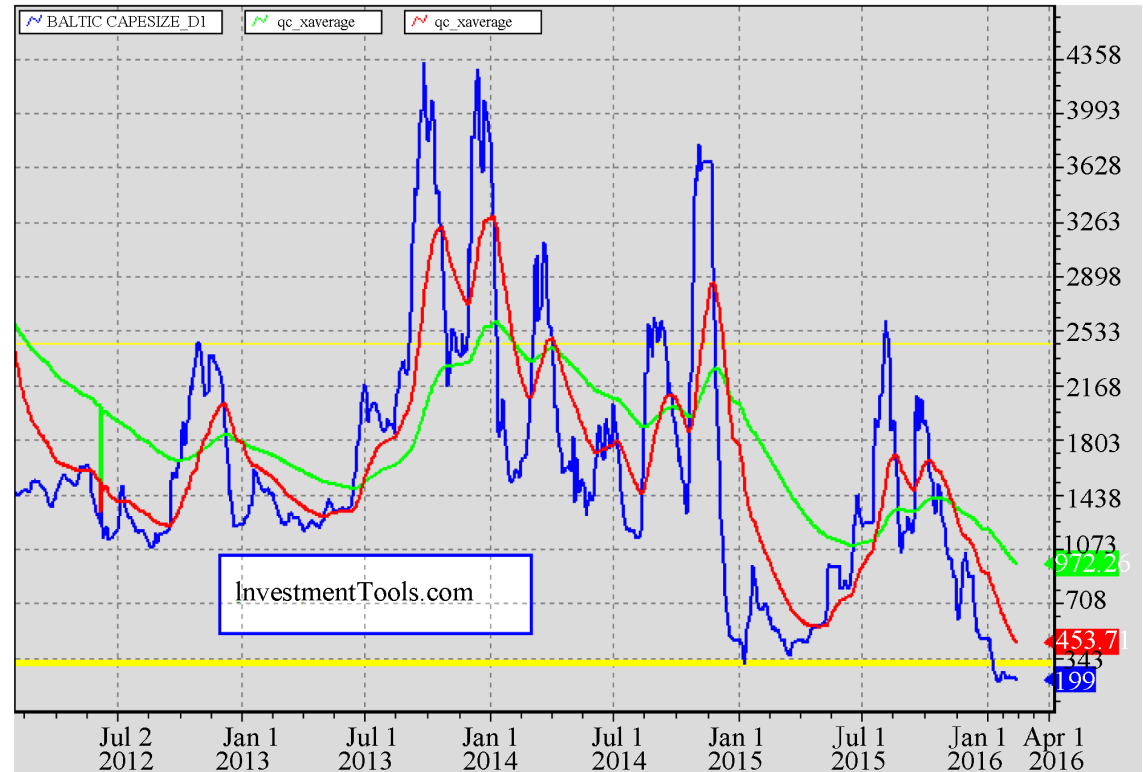

Figure 11. Baltic Capesize index of freight rates, 2012-2016. Source: Investment Tools. com.

\footnotetext{
${ }^{34}$ Following this matter in this year "Possidonia Maritime Exhibition" in June 2018, we saw the Chinese "Shanghai Waigaoqiao Shipbuilding Co Ltd." to sell the 400,000 dwt ore carrier of about $362 \mathrm{~m}$, about 399,000 $\mathrm{mt}$ at about $14.5 \mathrm{kn}$, under Hong Kong flag, and 7 hatches.

${ }^{35} \mathrm{BIMCO}$ estimated that Vale S.A.'s ships will replace 168 Capes or $15 \%$ of the existing fleet. A Cape ship has a size varying from 150,000 to 180,000 dwt and she goes round the Cape of Good Hope and this explains her name.
} 
Can "Valemax" technology win?

It needs "luck" - according to theory of IRS - in gaining early users (charterers) so that the eventual outcome to provide the maximum possible benefit...But "Valemax" gained no early adopters. The users (charterers) of these ships are the iron ore-importers, which depend, however, on national ports for these super-sized ships! "Vale S.A." did not secure the cooperation of either the ore importers or ports, as it should...

On 31/12/2012, the Ministry of Commerce of the PRC officially banned all dry bulk carriers, with a capacity exceeding 300,000 tons, from entering Chineseports in order... to protect domestic freight industry. ("Business Times": 02/02/2012)! This perhaps meant the Chinese owners of Capes... Some talked also about safety and environmental reasons. The ban cost for "Vale S.A." was from $\$ 800,000$ to $\$ 1,200,000$ per vessel...The members of company's board of directors replaced too.

The users that can be considered as potential adherents to Vale S.A. Valemax-apart from iron ore importers-are the 6 suitable ports worldwide-due to the size of the ship: Dalian (in China), Sohar (in OMAN), Rotterdam, Oita (in Japan), Dangjin (in S Korea) and Subic Bay (in Philippines; company's port). Ports, therefore, had to build suitable Valemax berths, but this takes 2 - 3 years (Lloyd's List 29/05/2012).

"Vale S.A." decided-wrongly apparently—to be dis-involved from shipping and focus on mining, and sell "Valemax" ships away, and perhaps charter them back...A complete failure of an extreme competitive vessel...due to management's tactical ${ }^{36}$ and strategic errors and chance events... As mentioned, this new sized ships are now available for all world shipowners.

$\checkmark$ Valemax ship-owners' another mistake

Shipowners do not pay attention to the impact that their additional supply will have on freight rates! In fact, they are displeased ${ }^{37}$ from low freight rates, but by their own oversupply they make them to fall further... E.g. the 36 "Valemax" till 2018 in service, provided $144 \mathrm{~m}$ tons extra supply (assuming 10 voyages per year one way)! Oversupply has to eliminate... over-supply, to restore total supply to total demand helped by scrapping.

$\checkmark$ The chance events

The above project did not attract the adherence of Chinese importers of iron ore, before ships were built, so that these ships to be admitted to Chinese ports (Lloyds List, 25/11/2011), and after ports have been prepared with proper berths. China was the "target group", but China also changed its development policy, which affected also iron ore imports. "Vale S.A." was-as a result-locked-in in an "antagonism" with China (Figure 12).

\footnotetext{
${ }^{36} \mathrm{~A}$ right move was to build the giant ships in China shipyards, but why to involve also S Korea? These shipbuilding contracts were wrongly timed before end-2008; they should be placed after end 2008 and secure-in exchange-admittance in China's ports...A win-win strategy. One right step and one half wrong step, committed by "Vale S.A."

${ }^{37}$ Freight rates fell $20 \%$ since 2008 and were then expected to drop further below the 1977 level (Lloyd's List, 22/10/2010).
} 


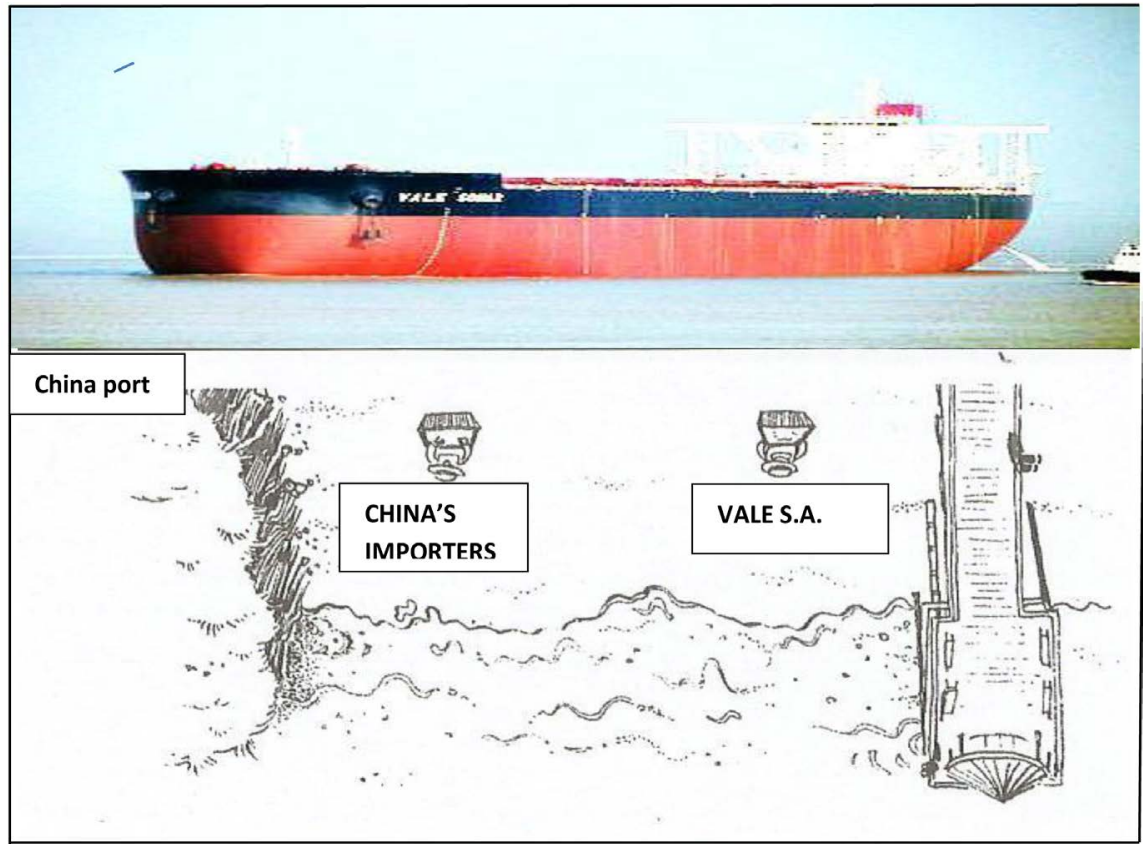

Figure 12. A vessel of a fantastic size is tangled in the opposing interests of Chinese shipowners and those of her shipowner Vale S.A. Source: Modified from that in Battram [29].

The above is an imaginary figure; it shows-on its top-a Valemax vessel, requesting admittance to a port of China. Chinese refuse... The persons shown, sitting there, are 1) those of CHINA's officials representing in fact Chinese ship-owners interests, and 2) "VALE S.A.". But, they both keep distances one to the other. On a more competitive thinking, both officers move at the same spot

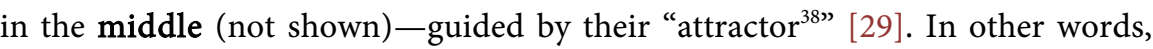
competition, or free market, drove them where one is closest to the other (back to back). This means that competition between the two became fiercer and the closeness of the competitors provided a better surveillance of one on the other. But this stuck them at the bottom of a "basin of attraction" 39 " (Figure 13).

\section{$\checkmark$ Conclusion from Figure 12}

Till rules change, the two will be locked-in competing hard for ever. Implicitly the picture above indicates a refusal to co-operate ${ }^{40}$.

$\checkmark$ Locked-in "spot" chartering, 2003-2008

We come now to another topic. "Once a solution is reached, it is difficult to exit from". This took place in 2003-2008 in all chartering markets, where shipowners locked-in to the extremely profitable spot market, till disaster came

\footnotetext{
${ }^{38}$ It is a model representation of the behavioral results of a system; it depicts where the system is heading on rules of motion; it comes from chaos theory (Battram, 1998, [29], p. 149).

${ }^{39}$ This term is often used to depict the idea that systems drift down into the attractor state from their initial position. The midpoint of the two negotiators presented in Figure 12 shows where the two are stuck at the bottom of the basin of attraction.

${ }^{40}$ In September 2014, "Vale S.A." realized our above argument and signed a framework agreement for strategic co-operation in iron ore shipping....with the State-owned COSCO and the China Merchants Group...
} 
(=end 2008 meltdown $)^{41}$. Figure 13 illustrates 2 lock-in situations that shipping found itself during 2003-2008 and in 2009-2018.

As shown (Figure 14), shipowners in 2003-2008, were gaining historical extremely high freight rates in the spot market (within red lines).

This situation locked-them-in the "spot market", and when spot market fell, they had to switch to "time charters", but they could not. So in economic life regrets exist. Here, the repositioning of the system is very difficult, but whoever can convince a shipowner in 2003-2004, that in 2009-2017 freight rate market is going to collapse?

In Goulielmos [30] it has been argued that out of interviews carried-out by my former student Mrs. Georgantzi K in 2005, in connection with her MSc thesis in City University, it has been showed that, if spot freight rate market is considered good and rising, ship-owners' strategy is to fix their vessels in the spot market (end 2003). When spot market reached its peak, shipowners chose time charters to retain the highest possible income (2004). If shipowners in fact considered as peak the 2004 situation (Figure 13), then they turned wrongly to time charters as... another much higher peak was about to come... in 2007. Indeed the exceptional profits came after $2006 \ldots$

The interviews showed that the majority of shipowners $(60 \%-80 \%)$ were in time charters when market peaked, but for the 2004 peak, and presumably not for the subsequent (2006) and stronger peak, lasting till almost end 2008! This means that shipowners are not in a position to forecast market's turning points...similarly with the rest of managers.

\section{Conclusions}

Modern theory presents only constant returns to scale with convex curves and

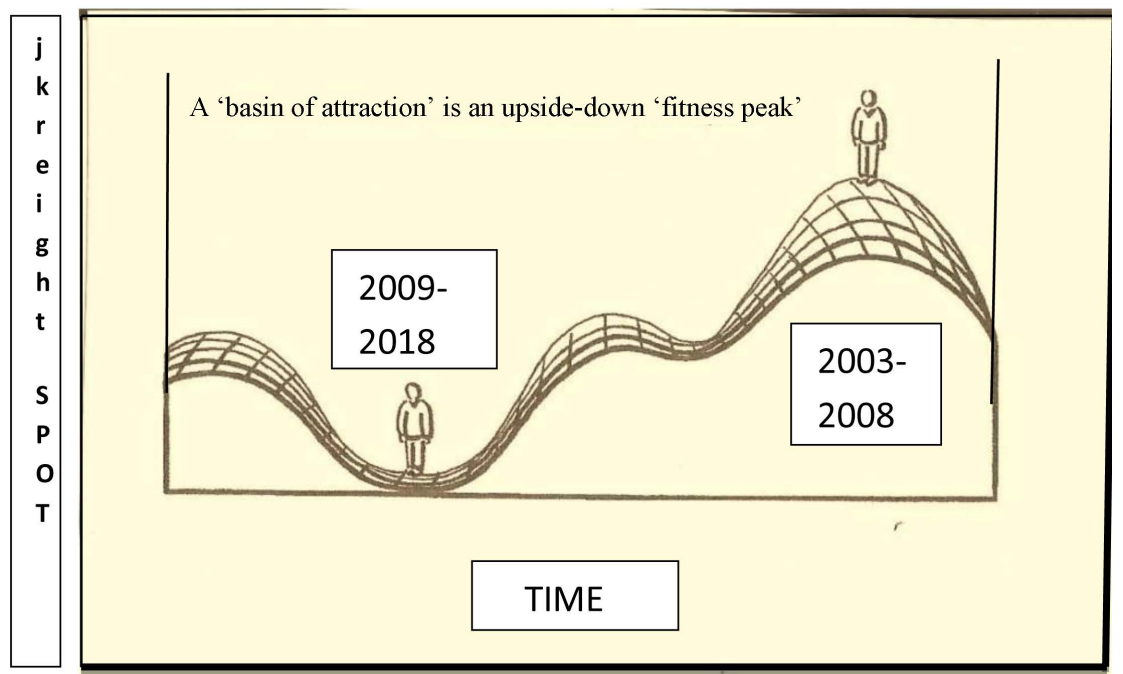

Figure 13. Shipowners locked-in in Spot Market in 2003-2008 and 2009-2018. Source: inspired and modified from Battram [29].

${ }^{41}$ This reminds us of the Noah and the Flood story in Bible, when people were locked-in their wrong and pleasant way of living, till a moment of no return came. 


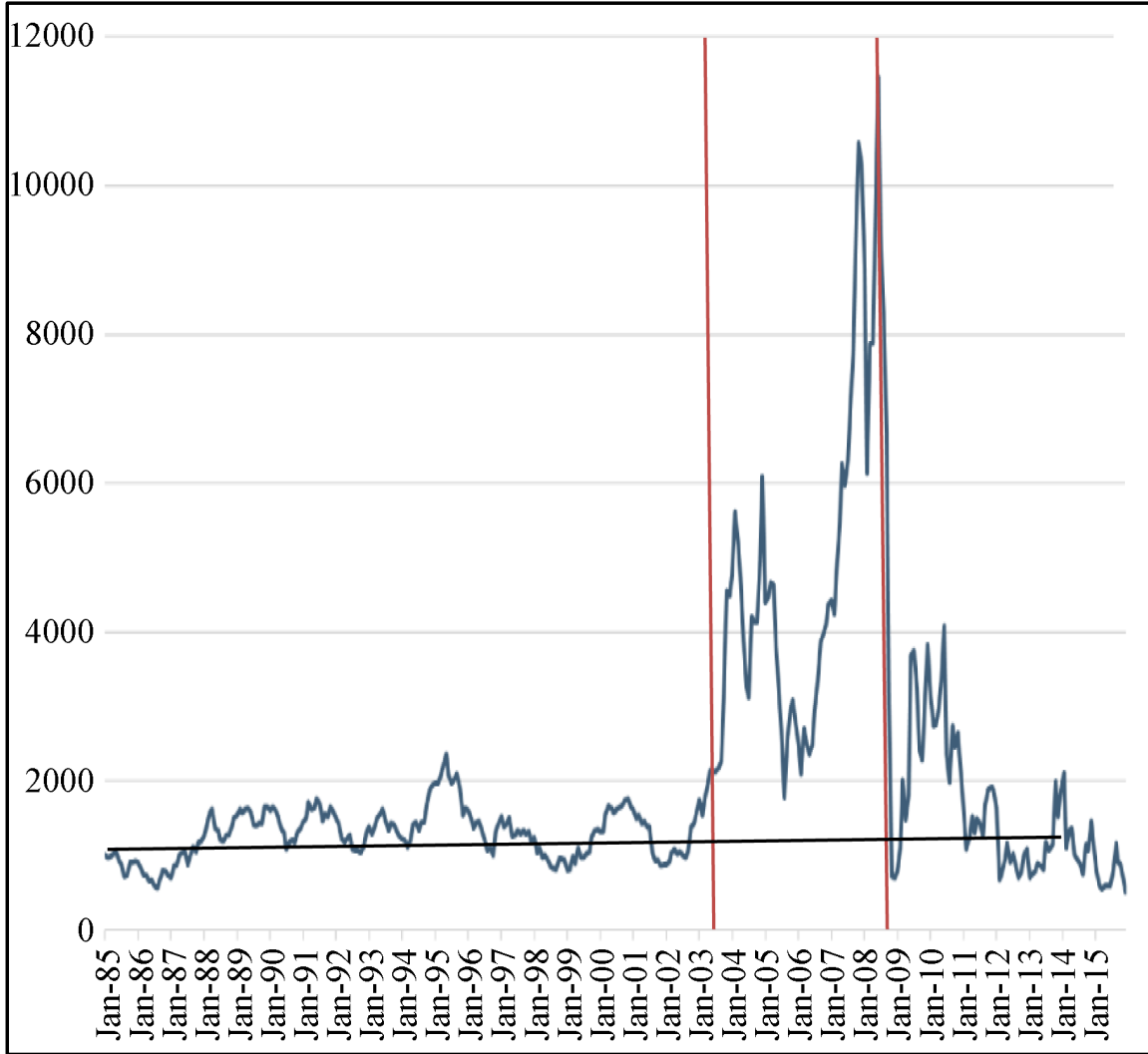

Figure 14. Baltic Dry Cargo index, 1985-2015. Source: Index of Baltic dry cargo-BDI.

one single equilibrium point, supported by famous economists like Schumpeter in 1954 and Varian in 1990. Economists at the time they constructed economic theory-i.e. at the time of Adam Smith in 1776-were open in examining all types of returns-constant, falling and increasing. In particular increasing returns showed them the road to monopoly, believing that as market gets larger, a particular firm and industry has no obstacles to become one seller.

The above possibility triggered a series of publications like those of Cournot on duopoly in 1838; Mill in 1848; of Chamberlin and Joan Robinson on economics of imperfect competition, in 1933, and so on. Paradoxically, Marshall spoke about oligopoly as well in connection with increasing returns.

We mentioned that in case of shipping there are trends towards larger sizes of companies (marriages among shipowners) and towards splitting of companies in two etc. (set off trends); for other companies the theory of "life cycle of products" has been presented.

As often happens, theoretical possibilities cannot be established if mathematical tools for this are missing. Increasing returns needed the proper mathematical tool-i.e. the "generalized Urn schemes of the Polya kind". As Battram [29] argued that though some economists have long recognized ${ }^{42}$ that increasing returns do occur in the economy, before Brian Arthur, they had no theory to ex${ }^{42}$ There are many examples like the economies of the Baden-Wurtttemberg, Silicon Valley, Route 128 and M4 corridor. 
plain it.

Conventional economics are different than recent economics (positive feedback). There are 10 differences [31]. In this paper we selected few topics from these 10: the lock-ins, which produce inefficiency in the market; history's crucial role; acknowledgment and study of increasing returns; and the fact that the market does not automatically "know best" [32].

The market of the giant iron ore Brazilian ships "Valemax" built in 2008 and thereafter, we saw, did not know well the (Chinese) market ... i.e. Chinese shipowners. Chance events-and managerial mistakes-destroyed the brilliant future of the Valemax ships, which was based on exceptional economies of scale by reducing $20 \%-25 \%$ the operating cost... They have beaten away the distance advantage of Australian iron ore to China. But history-which matters-has taught us that ports are "partners" of ships and they must be taken into account in all opportunities in advance.

Shipowners, as shown, were locked-in during the exceptional spot markets in 2003-2008, and when they wanted to switch to time charters, after $2004\left(1^{\text {st }}\right.$ peak), were unable to.

This analysis we believe can open the eyes of young economists from constant returns to scale to more interesting and challenging returns, i.e. increasing ones. Traditional economists argue that the absolute odds of being a billionaire are very low; but according to Pareto, the conditional probability of making a billion $\$$, once you have made $\$ 1 / 2 \mathrm{~m}$, is the same as that making a million once you have made $1 / 2$ a million [33]. Money begets money, power makes power-socially and mathematically...P(u) $=(u / m)^{-\alpha}$, where $P$ is the proportion of people earning more than $u$ (say $=\$ 107,120)$ in relation to some level of minimum income $m$ (say $=\$ 10,712$ ), and thus $u / m=10$ and $-\alpha=-3 / 2$. Thus $P(u)=$ $3.2 \%$ of the population, and only this \% can bring home $\$ 107,120$ per year...Life is unfair.

\section{Conflicts of Interest}

The authors declare no conflicts of interest regarding the publication of this paper.

\section{References}

[1] Smith, A. (1991) The Wealth of Nations. Everyman's Library, London.

[2] Cournot, A.A. $(1838,1927)$ Research into the Mathematical Principle of the Theory of Wealth. MacMillan, New York.

[3] Mill, J.S. (1848) Principles of Political Economy. Kelley, New York.

[4] Blaug, M. (1997) Economic Theory in Retrospect. 5th Edition, Cambridge University Press, Cambridge.

[5] Marshall, A. (1920) Principles of Economics. 8th Edition, MacMillan, New York.

[6] Goulielmos, A.M. (2017) The Great Achievement of Greek-Owned Shipping (1946-2017) and Keynes' Animal Spirits. Modern Economy, 8, 1186-1210. https://doi.org/10.4236/me.2017.810082 
[7] Arthur, W.B. (1994) Increasing Returns and Path Dependence in the Economy. University of Michigan Press, Ann Arbor.

[8] Walras, L. (1874) Elements of Pure Economics. Allen and Unwin, Crows Nest.

[9] Arrow, K.J. and Hahn, F.J. (1971) General Competitive Analysis. Holden Day, San Francisco.

[10] Katz, M. and Shapiro, C. (1985) Network Externalities, Competition and Compatibility. American Economic Review, 75, 424-440.

[11] Katz, M.L. and Shapiro, C. (1986) Technology Adoption in the Presence of Network Externalities. Journal of Political Economy, 94, 822-841. https://doi.org/10.1086/261409

[12] Kehoe, T.J. (1985) Multiplicity of Equilibria and Comparative Statics. The Quarterly Journal of Economics, 100, 119-147. https://doi.org/10.2307/1885738

[13] Schelling, T.C. (1978) Micromotives and Macrobehavior. Norton, New York.

[14] Varian, H.R. (1990) Intermediate Microeconomics: A Modern Approach. 2nd Edition, Norton, London.

[15] Krugman, P.P. and Obstfeld, M. (2002) International Economics: Theory and Policy. Pearson-Addison, New York.

[16] Fujita, M., Krugman, P. and Venables, A.J. (1999) The Spatial Economy: Cities, Regions and International Trade. MIT Press, Cambridge.

[17] Baldwin, R.E. (2003) Economic Geography and Public Policy. Princeton University Press, Princeton.

[18] Saxenian, A. (1994) Regional Advantage. Harvard University Press, Cambridge.

[19] Krugman, P. (1997) How The Economy Organizes Itself in Space: A Survey of the New Economics Geography. In: Arthur, W.B., Durlauf, S.N. and Lane, D.A., Eds., The Economy as an Evolving Complex System II, Westview Press, Boulder, 239-262.

[20] Arthur, W.B., Ermoliev, Y.M. and Kaniovski, Y.M. (1983) On Generalized Urn Schemes of the Polya Kind. Cybernetics, 19, 61-71.

[21] Goulielmos, A.M. (1974) A Vintage Model Approach to Some Problems of Shipping Economics. Unpublished PhD Thesis, Brunel University, London.

[22] Salter, W.E.G. (1969) Productivity and Technical Change. 2nd Edition, Cambridge University Press, Cambridge.

[23] Goulielmos, A.M. and Tzannatos, E. (1997) The Man-Machine Interface and Its Impact on Shipping Safety. Disaster Prevention and Management, 6, 107-117.

[24] Goulielmos, A.M. (2017) The "Kondratieff Cycles" in Shipping Economy since 1741 and till 2016. Modern Economy, 8, 308-332. https://doi.org/10.4236/me.2017.82022

[25] Stopford, M. (2009) Maritime Economics. 3rd Edition, Routledge, London. https://doi.org/10.4324/9780203891742

[26] Priesmeyer, H.R. (1992) Organizations and Chaos: Defining the Methods of Nonlinear Management. Quorum Books, Westport.

[27] Kotler, P. (1994) Marketing Management: Analysis, Planning, Implementation, and Control. 8th Edition, Prentice Hall, Upper Saddle River.

[28] Goulielmos, A.M. (2005) Complexity Theory: A Science Where Historical Accidents Matter. Disaster Prevention and Management, 14, 533-547. https://doi.org/10.1108/09653560510618366

[29] Battram, A. (1998) Navigating Complexity: The Essential Guide to Complexity 
Theory in Business and Management. The Industrial Society.

[30] Goulielmos, A.M. (2017) Strategies in "Shipping Business Management". Modern Economy, 8, 1211-1229.

[31] Waldrop, M.M. (1994) Complexity: The Emerging Science at the Edge of Order and Chaos, Penguin, London.

[32] Ormerod, P. (1996) Qwerty Input Is Key Explanation. The Guardian, 22/01.

[33] Mandelbrot, B. and Hudson, R.L. $(2006,2008)$ The (Mis)Behavior of Markets: A Fractal View of Financial Turbulence. Basic Books, New York. 